\title{
Distribution of sibling species of Anopheles culicifacies s.I. and Anopheles fluviatilis s.I. and their vectorial capacity in eight different malaria endemic districts of Orissa, India
}

\author{
Asima Tripathy', Luna Samanta², Sachidananda Das ${ }^{3}$, Sarat Kumar Parida', \\ Nitisheel Marai', Rupenansu Kumar Hazra', Santanu Kumar Kar', Namita Mahapatra1/+
}

${ }^{1}$ Regional Medical Research Centre, Indian Council for Medical Research, 751023 Bhubaneswar, Orissa, India ${ }^{2}$ Department of Zoology, Ravenshaw University, Orissa, India ${ }^{3}$ Department of Zoology, Utkal University, Orissa, India

The study was undertaken in eight endemic districts of Orissa, India, to find the members of the species complexes of Anopheles culicifacies and Anopheles fluviatilis and their distribution patterns. The study area included six forested districts (Keonjhar, Angul, Dhenkanal, Ganjam, Nayagarh and Khurda) and two non-forested coastal districts (Puri and Jagatsingpur) studied over a period of two years (June 2007-May 2009). An. culicifacies A, B, C and D and An. fluviatilis $S$ and $T$ sibling species were reported. The prevalence of An. culicifacies $A$ ranged from $4.2-8.41 \%, B$ from $54.96-76.92 \%$, C from 23.08-33.62\% and $D$ from 1.85-5.94\% ( $D$ was reported for the first time in Orissa, except for occurrences in the Khurda and Nayagarh districts). The anthropophilic indices (AI) were 3.2-4.8\%, 0.5-1.7\%, 0.7$1.37 \%$ and $0.91-1.35 \%$ for $A, B, C$ and $D$, respectively, whereas the sporozoite rates (SR) were $0.49-0.54 \%, 0 \%, 0.28$ $0.37 \%$ and $0.41-0.46 \%$ for $A, B, C$ and $D$, respectively. An. fluviatilis showed a similarly varied distribution pattern in which $S$ was predominant (84.3\% overall); its AI and SR values ranged from 60.7-90.4\% and $1.2-2.32 \%$, respectively. The study observed that the co-existence of potential vector sibling species of An. culicifacies $(A, C$ and $D)$ and An. fluviatilis $S(>50 \%)$ was responsible for the high endemicity of malaria in forested districts such as Dhenkanal, Keonjhar, Angul, Ganjam, Nayagarh and Khurda (> 5\% slide positivity rate). Thus, the epidemiological scenario for malaria is dependent on the distribution of the vector sibling species and their vectorial capacity.

Key words: sibling species - Anopheles culicifacies - Anopheles fluviatilis - vectorial capacity - anthropophilic index - sporozoite rate

Malaria is one of the major public health problems in India and it is an obstacle to the development of the nation (Sharma et al. 2006). The state of Orissa, which has $4 \%$ of the total population of India, accounts for $47 \%$ of Plasmodium falciparum cases and $34 \%$ of all reported deaths due to malaria in the country (Sharma et al. 2006). In India, the primary rural vector of malaria is Anopheles culicifacies (Ghosh et al. 2008) and Anopheles fluviatilis is the important vector in the hills and foothills (Sharma et al. 1995). Both An. culicifacies and An. fluviatilis are major vectors in Orissa and they exist as species complexes. An . culicifacies s.l. is a complex of five (A, B, C, D and E) species (Goswami et al. 2006), whereas An. fluviatilis s.1. is a complex of three ( $\mathrm{S}, \mathrm{T}$ and $\mathrm{U}$ ) species and a form $\mathrm{V}$ (Nanda et al. 2000, Manguin et al. 2008). Recent developments in vector biology have revealed that the vectorial capacity and competence of each sibling species is different, including their behavioral characteristics, breeding habitats, host specificity and susceptibility to malarial parasites and insecticides (Ghosh et al. 2008, Barik et al. 2009). Differences in the vectorial capacities and distribution patterns among sibling species are responsible for

Financial support: Indian Council for Medical Research

+ Corresponding author: nmrmrc@gmail.com

Received 30 March 2010

Accepted 28 September 2010 the wide variation in the endemicity of malaria in an area. Though a few reports regarding the species distribution in specific pockets of Orissa are available (Gunasekaran et al. 1989, Sahu et al. 1990, Sharma et al. 2006), no systematic study has been carried out on the characterization, distribution and vectorial capacity of the species complexes. With this background, the present study was undertaken in eight endemic districts of Orissa to find the distribution patterns of the species complexes of An. culicifacies and An. fluviatilis and their vectorial capacities.

\section{SUBJECTS, MATERIALS AND METHODS}

Geophysical location of Orissa - Orissa is located between latitude $17^{\circ} 49^{\prime}$ and $22^{\circ} 34^{\prime} \mathrm{N}$ and longitude $81^{\circ} 30^{\prime}$ and $87^{\circ} 30^{\prime}$ 'E along the shores of the Bay of Bengal on the east coast of India (Ranjit 2006). The study area included six forested districts, i.e., districts with $>30 \%$ forest area (Keonjhar, Angul, Dhenkanal, Ganjam, Nayagarh and Khurda) and two non-forested coastal districts (Puri and Jagatsingpur). Although Ganjam, Nayagarh and Khurda fall under the category of coastal belt due to their geographical locations, they have comparatively thick vegetation in most areas and are therefore categorized as forested districts.

Epidemiological data - The epidemiology of malaria was evaluated from the data collected by the State Government by considering the following parameters: number of blood slides collected, blood slides examined, slide positivity rate (SPR), slide $P$. falciparum rate and $P$. falciparum percentage. 
Mosquito collection - Resting indoor mosquitoes were collected from human dwellings in the morning between 6-9 am with the help of mechanical aspirators and CDC light traps. Attempts were made to collect the An. fluviatilis specimen based on its behavioral biting habits. Random samples were collected over a period of two years (June 2007-May 2009) at two-month intervals to include all seasons and areas of the represented districts. Species identification was done based on the taxonomic keys of Christophers (1933). All the entomological data were recorded for the calculation of different entomological indices. The perman hour density (PMHD) of all the collected anopheline species was calculated as the number of mosquitoes perman per-hour. An. culicifacies and An. fluviatilis were separated and each mosquito was dissected into two parts: the head-thorax and the abdomen. Head-thorax regions were kept separately in isopropyl alcohol for the identification of sibling species by an allele-specific polymerase chain reaction (ASPCR) assay. The abdomens of the blood-fed samples were subjected to multiplex PCR for the detection of the human blood index and P. falciparum sporozoites.

Molecular identification of the species complexes of An. culicifacies s.l. and An. fluviatilis s.l. - The total DNA was extracted from individual mosquitoes following a modified method of Collins et al. (1987). Morphologically identified An. culicifacies specimens were first assayed by the D3-PCR assay using primers from the D3 region of 28S rRNA, which distinguishes the five species into two categories: A/D and B/C/E (Singh et al. 2004b). The specimens identified as belonging to the species A/D category in the D3-PCR assay were subjected to the AD-PCR assay to differentiate species A-D. The samples identified as belonging to the species $\mathrm{B} / \mathrm{C} / \mathrm{E}$ category were subjected to the BCE-multiplex PCR assay to differentiate species $\mathrm{B}, \mathrm{C}$, and $\mathrm{E}$ from each other using targeted primers for the mitochondrial COII gene (Goswami et al. 2006). The expected fragment sizes in the AD-PCR assay were as follows: species A, 359 bp; species D, $166+359$ bp (Fig. 1A). Those for the BCE-PCR assay are as follows: species B, 248 bp; species C, $95+248$ bp; species E, $178+$ 248 bp (Fig. 1B). Similarly, an ASPCR assay was done to identify the sibling complex of An. fluviatilis following the protocol of Singh et al. (2004a), yielding an S-specific band of $295 \mathrm{bp}$ and a T-specific band of $128 \mathrm{bp}$, while U did not have any of these products. All three species had a common amplicon of $375 \mathrm{bp}$ (Fig. 1C).
Blood meal identification and sporozoite detection Human blood meal identification and sporozoite detection (Fig. 2) were done using a multiplex PCR method (Mohanty et al. 2007). Samples positive for human blood (the presence of human DNA) gave PCR fragments of $519 \mathrm{bp}$ and samples containing human blood with $P$. falciparum sporozoites gave fragments of $205 \mathrm{bp}$ (the presence of $P$. falciparum DNA) and 519 bp (the presence of human DNA). The number of identified human blood meals was recorded to calculate the anthropophilic index (AI), i.e., the percentage of vector species positive for human blood, while the recorded presence of $P$. falciparum sporozoites was used to calculate the sporozoite rate (SR) (the percentage of sporozoites found in samples positive for human blood).

\section{RESULTS}

PMHD of anophelines - A total of 5,417 anopheline mosquitoes were collected from the eight districts. This included nine species of anophelines: Anopheles aconitus, Anopheles annularis, Anopheles barbirostris, An. culicifacies s.1., An.fluviatilis s.1., Anopheles hyrcanus, Anopheles subpictus, Anopheles vagus and Anopheles varuna. Out of the nine anophelines collected, the major vectors were among the sibling species of An. culicifacies s.l. and An. fluviatilis s.l. The PMHDs of different districts are given in Table I. In all the districts, An. subpictus was found to be predominant, followed by An. vagus. The PMHD of An. culicifacies s.l. was found to vary from 2.5 in Jagatsingpur to 7.8 in Nayagarh, whereas that of $A n$. fluviatilis ranged from 0.5 in Dhenkanal to a maximum of 2.1 in Keonjhar. Apart from these two major vectors, An. annularis, which is known to be a local vector, was also found in this study. Its density ranged from 1.3-4.1. The densities of An. aconitus, An. barbirostris, An. hyrcanus, An. subpictus, An. vagus and An. varuna showed a wide range of PMHDs in the different study districts (Table I).

Sibling species percentage, AI and SR of An. culicifacies s.l. - The molecular identification of An. culicifacies s.l. showed the presence of four sibling species: A, B, C and D of An. culicifacies s.l. (Fig. 1A, B). An. culicifacies D was reported for the first time in Orissa. The highest prevalences of An. culicifacies A and D were seen in the district of Ganjam (8.41\% and 5.94\%, respectively). The Khurda district showed the predominance of species B (76.92\%), while species $\mathrm{C}$ was found to be more prevalent in the district of Angul (33.65\%) (Table II). The AI values for all the sibling
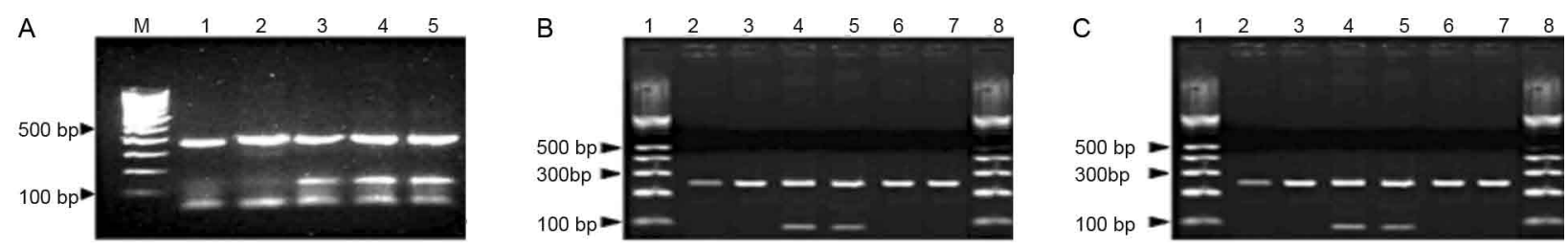

Fig. 1: ethidium bromide-stained agarose gel of allele-specific polymerase chain reaction (ASPCR) products for the differentiation of sibling species of Anopheles culicifacies s.l and Anopheles fluviatilis s.1. A: AD-PCR assay for the differentiation of species A and D [Lane M: 100 bp ladder; 1, 2: species A (359 bp); 3-5: species B (166 + 359 bp)]; B: BCE PCR assay for the differentiation of species B, C and E [Lanes 1, 8: 100 bp ladder; 2, 3, 6, 7: species B (248 bp); 4, 5: species C $(95+248$ bp) (species E not reported)]; C: ASPCR products for identification of species S, $\mathrm{T}$ and $\mathrm{U}$ [Lane 1: $100 \mathrm{bp}$ ladder; 2-4: species S (295 bp); 5-7, species T (128 bp) (species U not reported)]. 


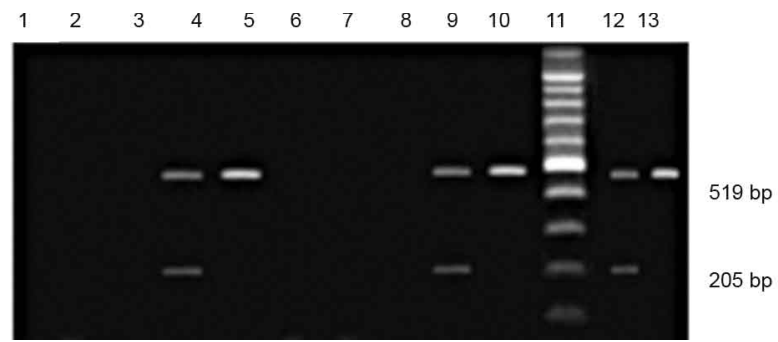

Fig. 2: ethidium bromide-stained agarose gel of multiplex polymerase chain reaction products for detection of Plasmodium falciparum sporozoite and human blood preference in the field-collected mosquitoes. Lane 1: negative control without any DNA template; 2: negative control with DNA from unfed Anopheles stephensi; 3: negative control with DNA from An. stephensi fed with rabbit blood; 4: DNA isolated from the blood of $P$. falciparum-infected persons; 5: DNA isolated from the blood from non-infected persons; 6-10, 12, 13: Anopheles culicifacies samples; 11: 100 bp DNA ladder. Samples from Lanes 6-8 negative for both human and $P$. falciparum DNA. Lanes 9 and 12 are positive for both human and $P$. falciparum (519 bp and $205 \mathrm{bp}$ respectively). Lanes 10 and 13 are positive only for human DNA (519 bp). species of the complex (A, B, C and D) were found to vary from $0.5-4.8 \%$ (Table II). An. culicifacies A was found to be more anthropophilic ( $4.08 \%$ overall AI) than the other three species. The overall $\mathrm{AI}$ values of $\mathrm{B}, \mathrm{C}$ and $\mathrm{D}$ are $1.11 \%, 1 \%$ and $1.11 \%$, respectively. Except for B, the other three species (A, C and D) showed SRs. The overall SRs of A, C and D were $0.52 \%, 0.33 \%$ and $0.43 \%$, respectively.

Sibling species percentage, AI and SR of An. fluviatilis s.l. - The sibling species composition identified by ASPCR (Fig. 1C) of An. fluviatilis s.l. showed the presence of $\mathrm{S}$ and $\mathrm{T}$, whereas species $\mathrm{U}$ and form $\mathrm{V}$ were not reported in the present study. A higher prevalence of $A n$. fluviatilis $\mathrm{S}$ was found over $\mathrm{T}$ in all the forested districts, including Angul, Nayagargh, Dhenkanal, Keonjhar, Khurda and Ganjam (Table III). The AI of An. fluviatilis $\mathrm{S}$ ranged from $60.7 \%$ in Ganjam to $90.4 \%$ in Angul. The $\mathrm{SR}$ of An. fluviatilis $\mathrm{S}$ was at a minimum for Ganjam and Nayagarh $(1.2 \%)$, was followed by Khurda $(1.4 \%)$ and then Dhenkanal and Angul (1.78\%) and recorded a maxi-

TABLE I

Per-man hour density of anophelines in different study districts of the state of Orissa, India

\begin{tabular}{lcccccccc}
\hline & \multicolumn{9}{c}{ Study districts } \\
\cline { 2 - 9 } Species & Nayagarh & Jagatsinghpur & Khurda & Dhenkanal & Keonjhar & Puri & Ganjam & Angul \\
\hline Anopheles aconitus & 1.20 & 0.66 & 0.80 & 0.70 & 1.30 & 0.30 & 0.90 & 1.50 \\
Anopheles annularis & 2.10 & 1.33 & 2.50 & 1.70 & 3.80 & 2.30 & 1.90 & 4.10 \\
Anopheles barbirostris & 1.00 & 0.30 & 0.30 & 0.20 & 0.40 & 0.10 & 0.20 & 0.40 \\
Anopheles culicifacies & 7.80 & 2.50 & 3.20 & 5.60 & 6.70 & 3.80 & 6.00 & 7.20 \\
Anopheles fluviatilis & 1.30 & - & 1.20 & 0.50 & 2.10 & - & 1.20 & 2.00 \\
Anopheles hyrcanus & 1.00 & 0.66 & 0.10 & 0.20 & 0.30 & 0.20 & 0.10 & 0.12 \\
Anopheles subpictus & 12.60 & 14.20 & 13.30 & 11.80 & 12.30 & 15.60 & 12.70 & 11.70 \\
Anopheles vagus & 11.70 & 7.33 & 12.50 & 10.60 & 13.20 & 14.20 & 10.80 & 11.10 \\
Anopheles varuna & 0.20 & 0.13 & 0.30 & 0.23 & 0.41 & 0.17 & 0.24 & 0.18 \\
\hline
\end{tabular}

TABLE II

District-wise distribution of sibling species (\% of total), anthropophilic index (AI) and sporozoite rate (SR) of Anopheles culicifacies A, B, C and D

\begin{tabular}{|c|c|c|c|c|c|c|c|c|c|c|c|c|}
\hline \multirow[b]{2}{*}{ Districts surveyed } & \multicolumn{3}{|c|}{ A } & \multicolumn{3}{|c|}{ B } & \multicolumn{3}{|c|}{$\mathrm{C}$} & \multicolumn{3}{|c|}{$\mathrm{D}$} \\
\hline & $\%$ & AI & SR & $\%$ & AI & SR & $\%$ & AI & SR & $\%$ & AI & SR \\
\hline Nayagarh & 4.2 & 3.2 & 0.49 & 62.18 & 1.2 & - & 33.62 & 0.7 & 0.3 & - & - & - \\
\hline Jagatsinghpur & - & - & - & 67.79 & 1.7 & - & 32.21 & 1 & 0.35 & - & - & - \\
\hline Khurda & - & - & - & 76.92 & 0.5 & - & 23.08 & 0.9 & 0.37 & - & - & - \\
\hline Dhenkanal & 4.45 & 4.1 & 0.53 & 64.67 & 0.9 & - & 28.34 & 0.8 & 0.33 & 2.54 & 1.2 & 0.45 \\
\hline Keonjhar & 5.57 & 3.9 & 0.54 & 64.72 & 1.1 & - & 27.86 & 1.1 & 0.35 & 1.85 & 1.35 & 0.41 \\
\hline Puri & - & - & - & 71.07 & 1.2 & - & 28.93 & 0.83 & 0.28 & - & - & - \\
\hline Ganjam & 8.41 & 4.4 & 0.51 & 54.96 & 1.3 & - & 30.69 & 1.31 & 0.31 & 5.94 & 0.91 & 0.41 \\
\hline Angul & 6.45 & 4.8 & 0.52 & 55.08 & 1 & - & 33.65 & 1.37 & 0.34 & 4.82 & 0.98 & 0.46 \\
\hline
\end{tabular}


mum for the district of Keonjhar (2.32\%) (Table III). The other two non-forested coastal districts, Jagatsingpur and Puri, showed an absence of An. fluviatilis S.

Malaria incidence in the different study districts The SPR showed a wide range of variation (0.84-16.13\%) among the studied districts (Table IV). The districts were divided into two categories based on the SPRs: (i) districts with $>5 \%$ SPR and (ii) districts with $<5 \%$ SPR. High SPR rates $(>10)$ were observed in the Dhenkanal, Angul and Keonjhar (16.13\%, $15.28 \%$ and $14.49 \%$, respectively). The malaria prevalence was found to be moderate $(>5 \%-<10 \%)$ in the Khurda, Nayagarh and Ganjam $(5.92 \%, 7.19 \%$ and $9.41 \%$, respectively). The forest coverage was more than $30 \%$ in all of the above six districts. Coastal districts, including Puri and Jagasingpur, showed lower malaria prevalences of $0.84 \%$ and $0.99 \%$, respectively (Table IV).

\section{TABLE III}

District-wise distribution of sibling species (\% of total), anthropophilic index (AI) and sporozoite rate (SR) of sibling species $\mathrm{S}$ and $\mathrm{T}$ of Anopheles fluviatilis s.1

\begin{tabular}{lccccc}
\hline & \multicolumn{3}{c}{ S } & \multicolumn{2}{c}{$\mathrm{T}$} \\
\cline { 2 - 6 } Districts surveyed & $\%$ & AI & SR & $\%$ & AI \\
\hline Nayagarh & 91.96 & 85 & 1.2 & 8.04 & 0 \\
Jagatsingpur & - & - & - & - & - \\
Khurda & 78 & 73.8 & 1.4 & 22 & 0 \\
Dhenkanal & 88.46 & 80.6 & 1.78 & 11.54 & 0 \\
Keonjhar & 88 & 78.26 & 2.32 & 12 & 0 \\
Puri & - & - & - & - & - \\
Ganjam & 66.66 & 60.7 & 1.2 & 33.34 & 0 \\
Angul & 92.72 & 90.4 & 1.78 & 7.28 & 0 \\
\hline
\end{tabular}

\section{DISCUSSION}

The transmission of malaria is governed by local and focal factors leading to vector(s) abundance under favorable conditions (Ghosh et al. 2008). Our study revealed the presence of nine anopheline species, with a predominance of the An. subpictus species followed by An. vagus and An. culicifacies, in all the studied districts of Orissa. In fact, a previous report by our group on the district of Angul showed An. subpictus to be the most prevalent (29\%) anopheline species, followed by, in order of prevalence, $A n$. vagus (19.7\%) > An. culicifacies and An. varuna $(11.6 \%)>$ An. annularis $(9.92 \%)>$ An. fluviatilis $(8.4 \%)>$ Anopheles nigerrimus (4.9\%) (Kumari et al. 2009). Tiwari et al. (1994) reported 10 anopheline species, with a predominance of An. subpictus followed by An. culicifacies and An. annularis, in the district of Allahabad (the basin of the Ganges River) of Uttar Pradesh, in northern India. The Anopheles pallidus and Anopheles tessellatus found in this northern state are not reported in the eastern coastal area surveyed in this study. Kulkarni (1987) also observed An. subpictus to be the most abundant species, along with the An. hyrcanus group, in the district of Bastar of Madhya Pradesh, in central India. The primary vectors An. culicifacies and An. fluviatilis constituted $15.8 \%$ and $2.6 \%$, respectively, of our collection, which did not corroborate the findings of Sharma et al. (2006) in the district of Sundargarh, Orissa. In their study, An. culicifacies and An. fluviatilis constituted $34.9 \%$ and $29.2 \%$, respectively, of the total collection. This discrepancy might be explained by considering that a district located entirely in the northern plateau would have a completely different habitat than the areas covered in the present study, which mostly included the coastal belt.

Four (A, B, C and D) out of the five sibling species (A, B, C, D and E) of An. culicifacies s.l. were prevalent in our study areas. The prevalence percentages of the An. culicifacies sibling species A, B, C and D in the state ranged from $4.2-8.41 \%, 54.96-76.92 \%, 23.08-33.65 \%$ and $1.85-5.94 \%$, respectively. A study by Nanda et al. (1996) in northern Orissa found the sibling species com-

TABLE IV

Epidemiological parameters of malaria incidence of the different districts of Orissa, India

\begin{tabular}{lccccccc}
\hline Districts surveyed & BSC & BSE & Positive & Pf & SPR & SFR & Pf \% \\
\hline Nayagarh & 89757 & 89460 & 6433 & 4256 & 7.19 & 4.75 & 66.16 \\
Jagatsinghpur & 24124 & 24124 & 240 & 130 & 0.99 & 0.53 & 54.17 \\
Khurda & 84183 & 84183 & 4992 & 1929 & 5.92 & 2.29 & 3.64 \\
Dhenkanal & 127188 & 127188 & 20517 & 15067 & 16.13 & 11.84 & 73.44 \\
Keonjhar & 281098 & 276138 & 40017 & 37590 & 14.49 & 13.61 & 93.94 \\
Puri & 60777 & 60777 & 515 & 48 & 0.84 & 0.078 & 9.32 \\
Ganjam & 187588 & 187588 & 17664 & 14687 & 9.41 & 7.82 & 83.15 \\
Angul & 71036 & 71036 & 10861 & 7728 & 15.28 & 10.87 & 71.15 \\
\hline
\end{tabular}

BSC: number of blood slides collected; BSE: blood slides examined; positive: malaria positive; Pf: slides showing presence of Plasmodium falciparum; Pf \%: P. falciparum percentage; SFR: slide P. falciparum rate (\% total slides examined having Pf); SPR: slide positive rate $(\%$ of total slides examined being positive for malaria). 
position of An. culicifacies s.l. to be $27.96 \%$ B, $71.1 \%$ C and $0.94 \% \mathrm{~B} / \mathrm{C}$ heterozygotes in the forested villages, whereas the non-forested villages having riverine ecosystems reported $0.48 \%, 21.1 \%, 77.94 \%$ and $0.48 \%$ of A, $\mathrm{B}, \mathrm{C}$ and $\mathrm{B} / \mathrm{C}$ heterozygotes, respectively, confirming the dominance of species $\mathrm{C}$ in that area. The dominance of species $\mathrm{C}$ was also observed in Karnataka, India, by Ghosh et al. (2005) and in Madhya Pradesh by Sharma et al. (2006). We found that in five districts (namely, Nayagarh, Dhenkanal, Keonjhar, Ganjam and Angul), the sibling species A, B and C of An. culicifacies s.l. were sympatric, whereas in Dhenkanal, Keonjhar, Ganjam and Angul, the A, B, C and D species were sympatric. On the other hand, $B$ and $C$ were sympatric in all eight of the districts. Nevertheless, species B is reported to be either without association, as in the northeastern parts of India, or in sympatric association with one or more of the other species (Subbarao 1998, Barik et al. 2009). In northern and southern India, species A and B are sympatric, whereas species $B$ and $C$ are sympatric in the western and eastern regions (Subbarao et al. 1999); species $\mathrm{D}$ has been found to be sympatric with species $\mathrm{A}$ and $\mathrm{B}$ in the northwestern region and with species $\mathrm{A}, \mathrm{B}$ and C in central India (Subbarao 1984, Barik et al. 2009), which is similar to our findings.

Like An. culicifacies s.l., An. fluviatilis s.l. also showed variation in its distribution pattern. Out of the three sibling species of An. fluviatilis s.l., only two (S and $\mathrm{T}$ ) were found in the six studied forested districts and they were absent in the two coastal non-forested districts. In our study, $\mathrm{S}$ was predominant (overall incidence $84.3 \%)$. This finding corroborates the previous reports by Gunasekaran et al. (1989) for the district of Koraput and Nanda et al. (1996) for the district of Sundargarh.

An. culicifacies s.l. and An. fluviatilis s.l. were prevalent throughout the year in some areas, especially from July-November, whereas very negligible densities were recorded in the month of April and rose to maximums during the irrigation season. The marked upward trend in July and August was entirely due to a significant increase in the number of available breeding places and has been shown to have a positive correlation with malaria incidence (Subbarao et al. 1988, Sharma et al. 2006, Barik et al. 2009).

The AI is one of the important parameters to give the actual frequency of human-mosquito contact and thus measures the transmission probability. The blood-feeding behavior of anopheline mosquitoes has been studied for the estimation of vectorial capacity and other epidemiological purposes (Parida et al. 2006). The ability of an Anopheles species to feed on human blood is generally defined as anthropophily and represents the success of a species and its capacity to transmit malaria (Ghosh et al. 2008). In this study, the overall AI of An. culicifacies s.l. was $1.83 \%$. A wide variation in the AI of An. culicifacies has been observed in different parts of India, such as $1.9 \%$ in Pune in Maharastra, 2.5\% in the districts of Puttukkottai and Tanjavur of Tamil Nadu, $10.1 \%$ in Visakhapatnam in Andhra Pradesh, 25.9\% in the Jeypore hills, $12.9 \%$ in the Singbhum hills in east central India, 3.2\% in Nadiad in Gujarat (overall, $1.9 \%$ in the state of Guja- rat), $12.5 \%$ in Haryana and Himachal Pradesh and 3.9\% in Shahjahanpur in Uttar Pradesh (Parida et al. 2006). In our study, the AI was $78.13 \%$ for An. fluviatilis (S). An AI of $78.9 \%$ for An. fluviatilis was also reported by Parida et al. (2006). Our study revealed the overall AI of An. culicifacies to be $4.08 \%, 1.11 \%, 1 \%$ and $1.11 \%$ for A, $\mathrm{B}, \mathrm{C}$ and $\mathrm{D}$, respectively. The above observations suggest that both An. culicifacies s.l. and An. fluviatilis s.l. exhibit different host preferences in different ecosystems.

The present study revealed that the SR of $\mathrm{An}$. $\mathrm{Cu}$ licifacies varied between $0.49-0.54$ for $\mathrm{A}, 0.28-0.37$ for $\mathrm{C}$ and $0.41-0.46 \%$ for $\mathrm{D}$, while $\mathrm{B}$ lacked any detectable sporozoite. The cumulative SRs for species A, C and $\mathrm{D}$ were reported to be $0.51 \%, 0.3 \%$ and $0.4 \%$, respectively (Subbarao \& Sharma 1997). An. culicifacies A has been established as the primary vector of malaria in Arabia (Akoh et al. 1984). The SR of An. fluviatilis S ranged from $1.2-2.32 \%$ in the present study. In Madhya Pradesh, a low rate of infection (i.e., 2.08 for gut and 1.2 for gland) was responsible for maintaining malaria transmission and endemicity by this species (Sharma et al. 1995) and a very high SR ranging from $13-37 \%$ had also been reported for the states of Karnataka, Kerala and Uttar Pradesh.

Subbarao et al. (1988) reported the presence of both $\mathrm{A}$ and $\mathrm{B}$ of An. culicifacies s.l. However, the authors reported the predominance of species $\mathrm{A}$ in areas with high malaria prevalence $(6-50 \%)$ and species B in areas with low malaria incidence in Uttar Pradesh. In the district of Allahabad of Uttar Pradesh, species A, B and C were sympatric with the predominance of species B. Nevertheless, the malaria incidence was high $(8.8 \%)$ where $\mathrm{A}$ and $\mathrm{C}$ were sympatric. Our study also confirms their findings in all the districts with high malaria incidence. In a malaria endemic region of northwestern Orissa, a longitudinal study carried out by Nanda et al. (1996) revealed an SPR of $45 \%$ for forested areas, which was significantly higher than that for the non-forested areas $(27 \%)$. In the district of Sundargarh, Sharma et al. (2006) also observed malaria incidences of $14 \%$ and $1.7 \%$ for the forested and plain areas, respectively, which have a prevalence of species C (38\% and $45 \%$, respectively) along with An. fluviatilis $\mathrm{S}$ in forested areas. We also observed a sympatric association between sibling species of An. culicifacies s.1. and An. fluviatilis s.l. in six of the surveyed districts, similar to the results of the study of Subbarao et al. (1992). In the districts of Nayagarh, Khurda, Dhenkanal, Keonjhar, Ganjam and Angul, both An. culicifacies s.l. and An. fluvatilis s.l. were sympatric. However, in these districts the sibling species $\mathrm{S}$ and $\mathrm{T}$ of An. fluviatilis s.l. were sympatric. In contrast, Sharma et al. (1995) found T and U of An. fluviatilis s.l. to be sympatric in their studied villages.

The prevalence percentages of vector species of $A n$. culicifacies s.l. (A, C and D) and An. fluviatilis $\mathrm{S}$ in the forested districts (Nayagarh, Khurda, Ganjam, Dhenkanal, Keonjhar and Angul) were $>50 \%$, with SPRs greater than 5\%. In the non-forested coastal districts, Puri and Jagasingpur, the prevalences of these species were $<20 \%$, with lower SPRs $(<1 \%)$. 
From this study, it is apparent that the wide variations of malaria prevalence seen in the studied districts were due to differential sympatric associations of sibling species of An. culicifacies s.l. and An. fluviatilis s.l. The presence of An. fluviatilis $\mathrm{S}$ in association with $\mathrm{An}$. $\mathrm{cu}$ licifacies $\mathrm{A}, \mathrm{C}$ and $\mathrm{D}$ might be primarily responsible for the high endemicity of malaria in the forested districts. The low prevalence of malaria in the coastal districts may be due to the presence of a single vector species, i.e., An. culicifacies C (31\%).

The sibling species of An. culicifacies are distinctly different in their vectorial capacity, responsiveness to insecticides and rate of the development of resistance (Barik et al. 2009). Therefore, there is a need to generate data on the transmission intensity in varied eco-epidemiological settings to guide malaria control operations. It is established that species B is a non-vector (Subbarao et al. 1999). Therefore, it is suggested to have stratification based on the distribution of sibling species An. fluviatilis s.l. and An. culicifacies s.l., with special emphasis on delimiting areas predominated by non-vectors, such as $A n$. culicifacies B and lacking An. fluviatilis S. The present study surmises the distribution, prevalence and vectorial capacity of the sibling species of two predominant vector species complexes of this highly malaria-endemic region and the findings have significance for malaria control in the state and elsewhere.

\section{ACKNOWLEDGEMENTS}

To the staff members of the Medical Entomology Division, GD Mansingh, B Pradhan, CS Tripathy, SS Beuria and G Simachallam, for their cooperation.

\section{REFERENCES}

Akoh JI, Beidas MF, White GB 1984. Cytotaxonomic evidence for the malaria vector species A of the Anopheles culicifacies complex being endemic in Arabia. Trans $R$ Soc Trop Med Hyg 78: 698-700.

Barik TK, Sahu B, Swain V 2009. A review on Anopheles culicifacies: from bionomics to control with special reference to Indian subcontinent. Acta Trop 109: 87-97.

Christophers SR 1933. The fauna of British India including Ceylon and Burma, vol. IV, Diptera family Culicidae, tribe Anophelinae, Taylor and Francis, London, $271 \mathrm{pp}$.

Collins FH, Mendez MA, Rasmussen MO, Mehaffey PC, Besansky NJ, Finnerty V 1987. A ribosomal RNA gene probe differentiates member species of the Anopheles gambiae complex. Am J Trop Med Hyg 37: 37-41.

Ghosh SK, Tiwari S, Raghavendra K, Sathyanarayan TS, Dash AP 2008. Observations on sporozoite detection in naturally infected sibling species of the Anopheles culicifacies complex and variant of Anopheles stephensi in India. J Biosci 33: 333-336.

Ghosh SK, Tiwari SN, Sathyanarayan TS, Sampath TR, Sharma VP, Nanda N, Joshi N, Adak T, Subbarao SK 2005. Larvivorous fish in wells target the malaria vector sibling species of the Anopheles culicifacies complex in villages in Karnataka, India. Trans R Soc Trop Med Hyg 99: 101-105.

Goswami G, Singh OP, Nanda N, Raghavendra K, Gakhar SK, Subbarao SK 2006. Identification of all members of the Anopheles culicifacies complex using allele-specific polymerase chain reaction assays. Am J Trop Med Hyg 75: 454-460.

Gunasekaran K, Sahu SS, Parida SK, Sadanandane C, Jambulingam P, Das PK 1989. Anopheline fauna of Koraput district, Orissa state, with particular reference to transmission of malaria. Indian J Med Res 89: 340-343.

Kulkarni SM 1987. Feeding behaviour of Anopheline mosquitoes in area endemic for malaria in Bastar district, Madhya Pradesh. Indian J Malariol 24: 163-171.

Kumari S, Parida SK, Marai N, Tripathy A, Hazra RK, Kar SK, Mahapatra N 2009. Vectorial role of Anopheles subpictus Grassi and Anopheles culicifacies Giles in Angul district, Orissa, India. Southeast Asian J Trop Med Public Health 40: 713-719.

Manguin S, Garros C, Dusfour I, Harbach RE, Coosemans M 2008. Bionomics, taxonomy, and distribution of the major malaria vector taxa of Anopheles subgenus Cellia in Southeast Asia: an updated review. Infection, genetics and evolution. Infect Genet Evol 8: 489-503.

Mohanty A, Kar P, Mishra K, Singh DV, Mohapatra N, Kar SK, Dash AP, Hazra RK 2007. Multiplex PCR assay for the detection of Anopheles fluviatilis species complex, human host preference, and Plasmodium falciparum sporozoite presence, using a unique mosquito processing method. Am J Trop Med Hyg 76: 837-843.

Nanda N, Joshi H, Subbarao SK, Yadav RS, Shukla RP, Dua VK, Sharma VP 1996. Anopheles fluviatilis complex: host feeding patterns of species S, T, and U. J Am Mosq Control Assoc 12: $147-149$.

Nanda N, Yadav RS, Subbarao SK, Joshi H, Sharma VP 2000. Studies on Anopheles fluviatilis and Anopheles culicifacies sibling species in relation to malaria in forested hilly and deforested riverine ecosystems in northern Orissa, India. $J \mathrm{Am}$ Mosq Control Assoc 16: 199-205.

Parida SK, Hazra RK, Marai N, Tripathy HK, Mahapatra N 2006. Host feeding patterns of malaria vectors of Orissa, India. $J$ Am Mosq Control Assoc 22: 629-634.

Ranjit MR 2006. The epidemiology of malaria in Orissa. ICMR Bull 36: 29-38.

Sahu SS, Parida SK, Sadanandane C, Gunasekaran K, Jambulingam P, Das PK 1990. Breeding habitats of malaria vectors: A. fluviatilis, A. annularis and A. culicifacies, in Koraput district, Orissa. Indian J Malariol 27: 209-216.

Sharma SK, Nanda N, Dua VK, Joshi H, Subbarao SK, Sharma VP 1995. Studies on the bionomics of Anopheles fluviatilis sensu lato and the sibling species composition in the foothills of Shiwalik range (Uttar Pradesh), India. Southeast Asian J Trop Med Public Health 26: 566-572.

Sharma SK, Tyagi PK, Padhan K, Upadhyay AK, Haque MA, Nanda N, Joshi H, Biswas S, Adak T, Das BS, Chauhan VS, Chitnis CE, Subbarao SK 2006. Epidemiology of malaria transmission in forest and plain ecotype villages in Sundargarh District, Orissa, India. Trans R Soc Trop Med Hyg 100: 917-925.

Singh OP, Chandra D, Nanda N, Raghavendra K, Sunil S, Sharma SK, Dua VK, Subbarao SK 2004a. Differentiation of members of the Anopheles fluviatilis species complex by an allele-specific polymerase chain reaction based on $28 \mathrm{~S}$ ribosomal DNA sequences. Am J Trop Med Hyg 70: 27-32. 
Singh OP, Goswami G, Nanda N, Raghavendra K, Chandra D, Subbarao SK 2004b. An allele-specific polymerase chain reaction assay for the differentiation of members of the Anopheles culicifacies complex. J Biosci 29: 275-280.

Subbarao SK 1984. Biological species in malaria vectors of India. Proceedings of the Indo-UK Workshop on Malaria, VP Sharma (ed.), Malaria Research Centre (ICMR), Delhi, p. viii-276.

Subbarao SK 1998. Anopheline species complexes in South-East Asia, Technical Publication 18, WHO South East Asia Regional Office, New Delhi, 81 pp.

Subbarao SK, Nanda N, Raghavendra K 1999. Malariogenic stratification of India using Anopheles culicifacies sibling species prevalence. ICMR Bull 29: 75-80.
Subbarao SK, Sharma VP 1997. Anopheline species complexes \& malaria control. Indian J Med Res 106: 164-173.

Subbarao SK, Vasantha K, Joshi H, Raghavendra K, Usha Devi C, Sathyanarayan TS, Cochrane AH, Nussenzweig RS, Sharma VP 1992. Role of Anopheles culicifacies sibling species in malaria transmission in Madhya Pradesh state, India. Trans $R$ Soc Trop Med Hyg 86: 613-614.

Subbarao SK, Vasantha K, Raghavendra K, Sharma VP, Sharma GK 1988. Anopheles culicifacies: sibling species composition and its relationship to malaria incidence. J Am Mosq Control Assoc 4: 29-33.

Tiwari SN, Prakash A, Subbarao SK, Roy A, Joshi H, Sharma VP 1994. Correlation of malaria endemicity with An. culicifacies sibling species composition and malaria antibody profile in district Allahabad (U.P.). Indian J Malariol 31: 48-56. 